\title{
O grotesco na representação das heroínas kleistianas Thusnelda e Penthesilea
}

Carina Zanelato Silva

UNESP

\begin{abstract}
Resumo
Este artigo tem como objetivo a comparação da exposição feita por Victor Hugo, em seu prefácio ao Cromwell, sobre o elemento grotesco com as ideias desenvolvidas por Heinrich von Kleist em seu Über das Marionettentheater (Sobre o teatro de marionetes, 1810), enfocando indícios de uma transgressão do escritor alemão da visão clássica de arte, trazendo à luz dessa discussão principalmente as teorias sobre estética de Friedrich Schiller. Além disso, propomos uma breve análise das peças de Kleist Penthesilea e Die Hermannsschlacht, publicadas em 1801, com base nessa dissolução do ideal clássico e no estabelecimento do intertexto com as propostas do Über das Marionettentheater.

Palavras-chave: Grotesco; Victor Hugo; Heinrich von Kleist; Friedrich
\end{abstract} Schiller.

\begin{abstract}
This article aims to compare the Victor Hugo's presentation, in his preface to Cromwell, on the grotesque element with Heinrich von Kleist's ideas developed in Über das Marionettentheater (1810), emphasizing evidence of a transgression concerning the classical view of art, mainly highlighting Friedrich Schiller's aesthetic theories. In addition, we propose a brief analysis of Kleist's pieces Penthesilea and Die Hermannsschlacht, published in 1801, based on this dissolution of the classical ideal and the establishment of intertextuality among with the proposals of the Über das Marionettentheater.
\end{abstract}

Keywords: Grotesque; Victor Hugo; Heinrich von Kleist; Friedrich Schiller. 
1. HUGO, Victor. Do grotesco e do sublime, 2007.
O Romantismo, através da valorização do fantástico, do estranho, da magia e pela inserção do elemento grotesco na arte, foi visto como um contraponto à harmonia e à perfeição desenvolvidas pelos clássicos, estabelecendo como projeto estético a aproximação da arte à vida, numa tentativa de alcance da verdade que norteia o ser. Victor Hugo, naquele espaço, colocou em evidência o grotesco, o feio, o baixo, indicando as mudanças nos padrões de composição artística e o nascimento do novo, da poesia que não mais se baseia na perfeição clássica e busca, na mescla dos contrários, alcançar o Absoluto romântico.

As ideias desenvolvidas por Hugo no seu prefácio ao Cromwell $(1827)^{1}$ levaram-nos a encontrar em algumas obras de Heinrich von Kleist indícios dessa nova proposta de arte, uma vez que a literatura kleistiana escapa à poesia que busca reconstruir o ideal grego de unidade perfeita; suas obras vão pelo caminho da dúvida e destacam sempre a desgraça como o grande destino do homem. Se, para os românticos, a quebra dos limites da poesia era necessária para uma maior aproximação com a vida que ela representa, o que Kleist faz é exatamente trazer para o seu texto personagens que representam o cotidiano conturbado, ultrapassando muitas vezes a margem que os separa do doentio. As injustiças em que a vida os coloca são tratadas sempre com fúria extrema, embora também mescladas ao belo e ao elevado. Essa descrença na ordem universal produz um tipo de arte que se pauta em paixões patológicas, em guerra, violência, desejo e, principalmente, na abdicação do estado de consciência, prezando pelo sonambulismo e pelo estado de êxtase bacante, que revelam personagens obsessivos, doentios.

Diante disso, este artigo objetiva, primeiramente, uma comparação entre a nova proposta de arte desenvolvida por Victor Hugo, em seu prefácio ao Cromwell, e os ideais clássicos de Friedrich Schiller, para, em seguida, observarmos como se dá a virada dessa visão clássica que foi desenvolvida por Heinrich von Kleist em Über das Marionettentheater. Essa discussão será exemplificada com uma breve análise de duas peças de Heinrich von Kleist, Penthesilea e Die Hermannsschlacht, publicadas em 1808, em que o elemento grotesco é de extrema importância para o estabelecimento do intertexto com as propostas do Über das Marionettentheater (1810).

\section{O grotesco e a bestialização do homem}

Com algumas variáveis conceituais, o termo grotesco foi de fundamental importância para a arte do Romantismo no século 
XIX, principalmente a partir das ideias desenvolvidas pelos pré-românticos alemães do Sturm und Drang e pelos primeiros românticos (Frühromantik). Para os Stürmer und Dränger Wieland, Möser e Lenz, segundo Kayser ${ }^{2}$, o grotesco é aproximado do cômico, da caricatura e da sátira, mas também figura ao lado do trágico, do terrível, do temor diante do estranhamento. Já para o romântico Friedrich Schlegel, em Conversa sobre a poesia (Gespräch über die Poesie, 1800) ${ }^{3}$, a busca de uma nova poesia, mais compatível aos sentimentos do homem moderno, e a valorização da subjetividade e da inconsciência parecem sustentar esse elemento na medida em que revelam as disparidades do eu e do mundo, que não conseguem mais conceber a harmonia clássica como forma artística. O mundo caótico dos românticos necessita de um elemento que expresse a ânsia e as contradições da vida, que revele o fantástico.

Essas ideias prepararam o terreno para o processo de consolidação do termo que, na diversidade de suas atribuições, partilha de características singulares: o elemento grotesco concilia o riso e o horror, o belo e o feio e, muitas vezes, passa para a via do sobrenatural, criando realidades que são permeadas pelo absurdo. A junção dos contrários torna-se a chave para que essa nova forma de concepção de arte dessacralize os padrões existentes por meio do choque diante do elemento grotesco. Há, assim, uma recusa aos ditames clássicos de imitação, e a estranheza revela o novo da arte. Kayser ${ }^{4}$ vê o grotesco a partir da imbricação do anormal na realidade, ligando-o ao horror, àquilo que é estranho à vida cotidiana. $\mathrm{O}$ onírico e o inconsciente, tão valorados pela estética romântica, são parte constituinte desse elemento que nos tira a dimensão de realidade, colocando-nos no patamar de mescla de realidade e sonho. Isso causa desorientação, horror, riso. As figuras elevadas se tornam grotescas, cometendo ações horrendas que revelam a bestialização do humano, como as personagens Penthesilea e Thusnelda de Heinrich von Kleist, ou são figuras deformadas que mostram a elevação de seu caráter, como o Quasímodo, de Victor Hugo.

O prefácio ao Cromwell, de Victor Hugo, escrito em 1827, além de ser um notável manifesto em defesa da obra que o segue e de todas as inovações que definiriam a sua concepção de drama moderno, apresenta-nos o elemento grotesco como o operador de uma nova forma artística que se diferencia da arte produzida na Antiguidade Clássica.

Para Victor Hugo ${ }^{5}$, os estágios pelos quais passou a humanidade podem ser representados por três formas de arte: nos tempos primitivos, figurava o lirismo; nos tempos antigos, a epopeia; e nos tempos modernos, o drama. Essa periodização se dá porque, segundo ele, nos tempos primitivos, havia uma
2. KAYSER, Wolfgang.

O grotesco: configuração na

pintura e na literatura, 1986.

3. SCHLEGEL, Friedrich.

Conversa sobre a poesia e fragmentos, 1994.

4. KAYSER, Wolfgang. O grotesco: configuração na pintura e na literatura, 1986.

5. HUGO, Victor. Do grotesco e do sublime, 2007. 
aproximação maior do homem com seu estado natural, com Deus; e a poesia, portanto, era-lhe natural. Quando as populações tornaram-se grandes demais e começaram a lutar por territórios, a poesia acompanhou esse crescimento e passou a representar o ambiente em que estava inserida: as guerras necessitavam da poesia épica que cantasse seus povos, seus heróis; e a tragédia antiga, ainda que possuísse uma forma diferente, era toda ela epopeia, pois pintava também o quadro dessa sociedade permeada de guerras, heróis e deuses. Esses dois estágios da humanidade foram marcados pela perfeita harmonia e união entre arte, política e religião, o que caracterizava a unidade do homem antigo.

Porém, no mundo moderno, há uma cisão do homem pela religião cristã: ele é agora constituído de espírito e matéria, corpo e alma, e há de viver uma vida terrena para poder alcançar a vida plena no céu. Essa quebra de unidade suscitada pela compreensão de que Deus está muito longe do mundo terreno fará com que o homem desperte para um novo sentimento, "um sentimento que é mais que a gravidade e menos que a tristeza: a melancolia". Ela é reflexo da meditação das pessoas diante das desgraças a que estão expostas, é a abertura de visão delas para si mesmas e para o mundo. Assim, a poesia representante desse estágio não pode mais se deter à unidade e à harmonia existentes na Antiguidade; ela deve pintar o abalo sofrido pelas pessoas e as suas novas formas de perceber o mundo. Portanto, a nova poesia pôr-se-á

a fazer como a natureza, a misturar nas suas criações, sem entretanto confundi-las, a sombra com a luz, o grotesco com o sublime, em outros termos, o corpo com a alma, o animal com o espírito, pois o ponto de partida da religião é sempre o ponto de partida da poesia. Tudo é profundamente coeso. ${ }^{7}$

Se, na Antiguidade, a épica mostrava apenas o belo ao narrar os feitos heroicos - e o grotesco, quando ali aparecia, era voltado para gêneros que tratavam de homens baixos e assunto ignóbil, como a comédia -, o feio, o disforme deverá ser desmascarado com o advento do cristianismo e dessa nova forma de poesia; devem-se ampliar os horizontes perceptivos para que a realidade, em todas as suas formas, seja alcançada e, assim, a poesia represente a verdade. O grotesco é introduzido na poesia e torna-se o traço separador entre arte antiga e moderna, entre literatura clássica e romântica:

O cristianismo conduz a poesia à verdade. Como ele, a musa moderna verá as coisas com um olhar mais elevado e mais amplo. Sentirá que tudo na criação não é 
humanamente belo, que o feio existe ao lado do belo, o disforme perto do gracioso, o grotesco no reverso do sublime, o mal com o bem, a sombra com a luz. ${ }^{8}$

É válido lembrar que, antes de Victor Hugo, Friedrich Schiller e Heinrich von Kleist haviam teorizado, em fins do século XVIII e início do XIX, sobre a fragmentação característica do homem moderno e a unidade dos clássicos. No poema "Os artistas" ("Die Künstler"), de 1789, Schiller traça uma linha do tempo do desenvolvimento da arte, e consequentemente do desenvolvimento humano, estabelecendo um contraponto entre a arte produzida pelo homem em estado de inocência e em estado de razão. Iniciando pelo seu despertar para a aparência, Schiller diz-nos que a beleza já estava revelada ao homem naturalmente em seu estado de inocência e que, a partir de sua atração por ela, a primeira obra de arte desenvolvida pelo homem foi feita por suas mãos através daquilo que era proveniente da natureza. A isto seguiu-se a habilidade de representar a si mesmo, e logo o homem já era capaz de traduzir em imagens seus pensamentos. Portanto, para Schiller, a beleza funcionou como meio para a inserção do homem no "país do conhecimento": "Nur durch das Morgentor des Schönen / Drangst du in der Erkenntnis Land"'.

Ainda na poesia antiga, na épica de Homero e nas tragédias antigas gregas, percebe-se que a harmonia reinava no homem, que não fazia distinção entre aquilo que dele exigia a necessidade ou a razão, pois as duas estavam em perfeita consonância:

Gelassen hingestützt auf Grazien und Musen, Empfängt er das Geschoß, das ihn bedräut, Mit freundlich dargebotnem Busen Vom sanften Bogen der Notwendigkeit. ${ }^{10}$

Porém, com a alegoria da expulsão do homem pelo Criador do paraíso da perfeita harmonia, Schiller descreve a amplitude que o pensamento racional alcançou no homem, ocasionando sua fragmentação nas instâncias sensível e racional, que teriam de ser reunidas novamente depois de um processo árduo e longo que o encaminharia em direção à luz. Nesse processo, a razão deveria alcançar total maturação para que fosse possível a apreensão da beleza proveniente de sua harmonia. O homem moderno, assim fragmentado, já não mais tem a beleza revelada a ele de forma natural como em seu estado de inocência; a razão que a ele sobreveio cultivada pela beleza, penosamente busca encontrar a beleza proveniente do estado de conciliação entre sua razão e sua sensibilidade. Assim, a razão somente o encontra depois de ter chegado à "velhice", percorrendo o árduo caminho em busca de reconciliação. Em vista disso, no poema, a
8. Ibidem, p. 26.

9. "Somente através do portal matinal da beleza penetras tu no país do conhecimento". SCHILLER, Friedrich. Ausgewählte Werke, 1950, p. 135. (Todas as traduções de citações do poema Die Künstler são de minha autoria).

10. "Apoiado tranquilamente sobre Graças e Musas, recebe ele com o peito, que oferece amigavelmente, o dardo iminente do suave arco da necessidade". Ibidem, p. 144. 
11. "Aquela, cuja face é de Orion, uma Glória, em augusta majestade, somente pelos espíritos mais puros contemplada, ardendo avança sobre as estrelas, de seu trono solar fugida, a terrível e admirável Urania com a coroa de fogo deposta permanece ela aqui, como a beleza, ante nós, vestida com o cinto da graça torna a ser criança para ser por crianças compreendida: o que nós como beleza aqui sentimos, tornará um dia ao nosso encontro como verdade". Ibidem, p. 135-136.

12. "Da poesia a sagrada magia serve a um sábio plano do universo. Silenciosa conduz até o oceano da grande harmonia!". Ibidem, p. 149.

13. SCHILLER, Friedrich. Sobre poesia ingénua e sentimental, 2003. beleza que era sentida pelo homem antigo, em estado de razão, deverá retornar como verdade:

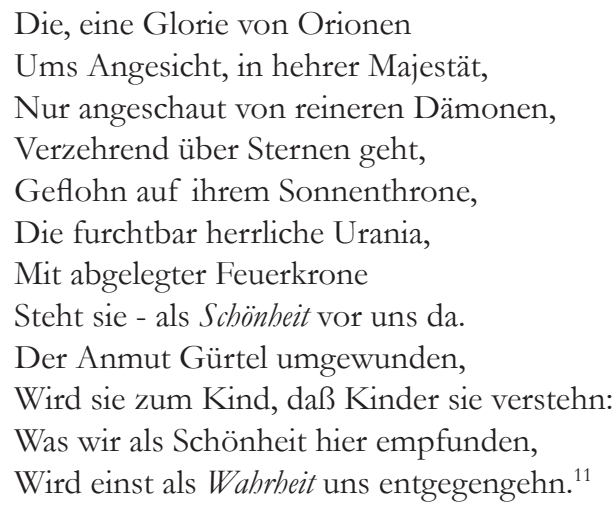

A deusa da beleza, adornada com seu cinto gracioso, possui a forma da inocência, da criança, o que lhe permite sentir a beleza. Porém, como o retorno do homem ao paraíso não será mais em estágio de inocência, mas sim de conhecimento, a beleza não mais será vista por esse homem como beleza, mas como verdade. É interessante observar que o que o homem em estado de razão busca desesperadamente como verdade está, em estado ingênuo, diante de seus olhos como beleza. Isso deixa claro, para Schiller, que não é preciso uma busca desenfreada por essa verdade; basta que o homem aprenda a olhar o mundo através de seu olhar estético, e, portanto, clássico, para perceber que ela não se esconde da luz do pensamento esclarecido.

Porém, para aprender a olhar o mundo dessa forma, o homem deve buscar na poesia a verdade, pois foi lá que ela encontrou refúgio após a sua fragmentação:

Der Dichtung heilige Magie

Dient einem weisen Weltenplane,

Still lenke sie zum Ozeane

Der großen Harmonie! $!^{12}$

A poesia possui o poder de conduzir o homem até o "oceano da grande harmonia", e, assim, fazê-lo constituir-se de unicidade. Só ela é capaz de conduzir-nos até a luz deixada pelo Criador para o retorno ao paraíso.

Posteriormente, em Sobre poesia ingênua e sentimental $(1795)^{13}$, Schiller dirá que a categoria do ingênuo permanece em nós como a infância perdida, que é despertada através da contemplação da natureza, que suscita à memória essa ideia criada daquilo que é ingênuo, causando a comoção sublime. Para Schiller, quando contemplamos um objeto da natureza, como um pássaro, vemos nele a representação de um ideal a ser buscado: a perfeição. A unidade da natureza remete-nos ao que almejamos 
ser e ao que éramos antes de perder o caráter ingênuo. Sentimos nostalgia dessa ingenuidade provinda da natureza, pois estamos imersos em cultura, que, racionalmente, nos afasta da perfeição.

A arte, por sua vez, vem como a voz que nos faz recordar desse estado de inocência, e, assim, a única volta possível a esse ingênuo natural seria através da cultura, conduzida agora pela razão e pela sensibilidade:

Com um doloroso desejo sentimos a nostalgia do regresso logo que principiamos a experimentar os martírios da cultura, e ouvimos no exílio distante da arte a voz comovente da mãe. Enquanto éramos simples filhos da natureza éramos felizes e perfeitos; tornamo-nos livres e perdemos ambas as coisas. ${ }^{14}$

As ideias de Schiller, portanto, buscam a plenitude clássica e relegam somente à perfeição e à beleza a possibilidade de alcance do paraíso perdido, ou seja, da unidade que constituía o homem, o que está em oposição à nova poesia buscada pelos românticos, que encontrarão na contradição o meio de revelar a verdade do mundo.

Já em Heinrich von Kleist, percebemos que há uma mudança nos parâmetros de alcance da plenitude. Em Über das Marionettentheater (Sobre o teatro de marionetes, 1810) ${ }^{15}$, Kleist constrói o seu texto numa espécie de diálogo socrático, em que, através de uma discussão quase teatral entre o narrador e um bailarino, é criada uma grande teia filosófica sobre os desdobramentos da inserção do homem na cultura, que o afastou da inocência original.

Nessa narrativa, partindo da figura da marionete como ser perfeito, pois é destituído de qualquer rastro de consciência, e da passagem bíblica da expulsão do homem do paraíso, Kleist utiliza-se de duas parábolas que são muito elucidativas quanto às fases do desenvolvimento humano. Na primeira, o narrador conta ao bailarino uma história que comprova "as desordens que a consciência provoca na graça natural do homem"16. Um dia, o narrador estava banhando-se com um jovem provido de uma "graça prodigiosa" ("wunderbare Anmut") quando este, ao pousar os pés sobre um banco para secá-los e olhar-se no espelho, percebeu que havia feito um movimento gracioso, que lhe recordava a inocência e a graciosidade de que era provida uma escultura grega, o Espinário. Ao perceber esse movimento, contou ao narrador a sua descoberta, porém este, ainda que também tenha feito a mesma analogia, disse-lhe que não havia percebido nada. O jovem, na tentativa de provar o ocorrido, passou a repetir o movimento por inúmeras vezes, porém não conseguia alcançar a graça do movimento original, pois a sua consciência impedia-o de repetir a graça natural, que somente
14. Ibidem, p. 54.

15. KLEIST, Heinrich von. Der Zweikampf, Die heilige Cäcilie, Sämtliche Anekdoten, Über das Marionettentheater und andere Prosa, 2012.

16. Idem. Sobre o teatro de marionetes, 1998. (Todas as traduções de citações desse texto são de autoria de José Filipe Pereira, Edição: ACTO. Instituto de Arte Dramática, 1998.) " [...] welche Unordnungen, in der natürlichen Grazie des Menschen, das Bewusstsein anrichtet." Idem. Der Zweikampf, Die heilige Cäcilie, Sämtliche Anekdoten, Über das Marionettentheater und andere Prosa, 2012, p. 84. 
17. Idem. Der Zweikampf, Die beilige Cäcilie, Sämtliche Anekdoten, Über das Marionettentheater und andere Prosa, 2012, p. 86. “[...] os seus olhos nos meus, como se pudera ler a minha alma, ficava com a garra levantada, pronto a atacar e, quando os meus ataques não eram senão esboçados, não se movia". Idem. Sobre o teatro de marionetes, 1998, p. 6.

\section{Idem. Der Zweikampf, Die} beilige Cäcilie, Sämtliche Anekdoten, Über das Marionettentheater und andere Prosa, 2012, p. 86-87.

"Vemos que no mundo orgânico quanto mais a reflexão parece fraca e obscura mais a graça é soberana e radiante. - No entanto, como a intersecção de duas linhas situadas do mesmo lado de um ponto se encontra subitamente do outro lado, após haver atravessado o infinito, ou como a imagem dum espelho côncavo retorna subitamente junto a nós depois de se ter afastado até ao infinito: assim retorna a graça quando a consciência passou ela também por um infinito; de maneira que ela aparece sob a sua forma mais pura nesta anatomia humana que não tem qualquer consciência, ou que tem uma consciência infinita, isto é, num manequim, ou num deus. — Em consequência, disse-lhe eu um pouco sonhador, deveríamos comer uma vez mais o fruto da Árvore do Conhecimento, para recair no estado da inocência? - Sem qualquer dúvida, respondeu-me; é o derradeiro capítulo da história do mundo". Idem. Sobre o teatro de marionetes, 1998, p. 7. é proveniente de movimentos inconscientes. Assim, passado algum tempo, a frequência com que o jovem intentava reproduzir o movimento deixou-o sem qualquer rastro do encanto que lhe era próprio.

$\mathrm{Na}$ segunda parábola, o bailarino conta ao narrador que estava viajando pela Rússia e encontrava-se na casa de um senhor amigo seu quando o filho mais velho deste convidou-o para praticar esgrima. O bailarino, derrotando facilmente o jovem, é desafiado por ele a enfrentar um urso que seria páreo para ele na esgrima. Estupefato diante do urso, o bailarino começa a atacá-lo, porém o urso rebatia simplesmente todos os movimentos que ele realizava: "Aug in Auge, als ob er meine Seele darin lesen könnte, stand er, die Tatze schlagfertig erhoben, und wenn meine Stöße nicht ernsthaft gemeint waren, so rührte er sich nicht" ${ }^{\prime 17}$.

No ensaio, essas duas narrativas permitem-nos associar a plenitude do homem às duas extremidades a que o mundo circular nos encaminha: se a primeira parábola mostra a perda da graça, da beleza, através da perda da inocência, a segunda eleva a figura do urso à divindade: ao rebater cada ataque do bailarino como se previsse as intenções dos seus movimentos, como se lesse em sua alma a forma do movimento, o urso age como o Deus que possui consciência total. O jovem desprovido de consciência (a marionete, portanto) e o urso são, para Kleist, representativos das duas portas do paraíso: o homem partiu da primeira e deve chegar à segunda. Assim, o bailarino e o narrador concluem que

Wir sehen, daß in dem Maße, als, in der organischen Welt, die Reflexion dunkler und schwächer wird, die Grazie darin immer strahlender und herrschender hervortritt. - Doch so, wie sich der Durchschnitt zweier Linien, auf der einen Seite eines Punkts, nach dem Durchgang durch das Unendliche, plötzlich wieder auf der andern Seite einfindet, oder das Bild des Hohlspiegels, nachdem es sich in das Unendliche entfernt hat, plötzlich wieder dicht vor uns tritt: so findet sich auch, wenn die Erkenntnis gleichsam durch ein Unendliches gegangen ist, die Grazie wieder ein; so, daß sie, zu gleicher Zeit, in demjenigen menschlichen Körperbau am reinsten erscheint, der entweder gar keins, oder ein unendliches Bewußtsein hat, d. h. in dem Gliedermann, oder in dem Gott. Mithin, sagte ich ein wenig zerstreut, müßten wir wieder von dem Baum der Erkenntnis essen, um in den Stand der Unschuld zurückzufallen? Allerdings, antwortete er, das ist das letzte Kapitel von der Geschichte der Welt. ${ }^{18}$

A metáfora religiosa da expulsão do homem do paraíso evocada por Kleist é poetizada e transposta para a estética, criando a imagem do homem que perde a sua plenitude e tem 
agora de viver sob o signo do fragmento, da realidade assoladora. A árvore do conhecimento tirou dele a inocência, e ela deve, agora, fazê-lo avançar ao infinito da consciência através de seu fruto. À queda do homem descrita na Bíblia, originada pelo fruto da árvore do conhecimento, conflui a sua fragmentação, também presente em Schiller, ocasionada pelo desenvolvimento do conhecimento humano. Se a paridade que liga a teoria de Kleist à de Schiller é reconhecida pela atribuição da fragmentação do homem ao conhecimento e à posterior unidade que perpassa o caminho desse mesmo conhecimento, o seu afastamento se dá justamente na forma como o homem deverá percorrer esse caminho. Em Schiller, essa volta se dá pela educação estética, que conciliará harmoniosamente os polos de que o homem é constituído: natureza sensível e racional, prezando uma unidade clássica. Porém, em Kleist, longe do equilíbrio atestado por Schiller, a disjunção entre graça e razão atinge proporções irreversíveis, que necessitarão do abate de uma ou outra para que a plenitude possa ser novamente alcançada. Kleist fundamenta que a volta somente será permitida pelo máximo conhecimento, adquirido quando o homem provar novamente da árvore do conhecimento, e não através de um processo de educação estética, de imitação de um modelo que, para ele, mostra-se falho.

Segundo Hohoff ${ }^{19}$, os estágios de desenvolvimento da consciência descritos nesse texto lembram a psicologia romântica, o cristianismo e sua teoria sobre a graça, porém o que fica mais evidente é que todas essas ideias foram concatenadas por Kleist para articular um "sistema" com base na doutrina gnóstica da autorredenção. Se o gnosticismo é baseado na crença de que o homem somente consegue se libertar dos sofrimentos do mundo através do conhecimento - conhecimento este não de base científica, mas sim transcendental -, o que Kleist mostra em seu Teatro de marionetes é que o homem, ao conhecer-se a si mesmo e ao mundo por meio de um conhecimento intuitivo, e não científico ou mimético, conseguirá encontrar a salvação, o retorno ao paraíso. Essa é a diferença básica entre a forma de obtenção da plenitude do homem em Schiller e em Kleist, o que faz este aproximar-se mais dos ideais românticos de valorização da inconsciência, da intuição.

Essa busca da verdade absoluta em Kleist, assim, não deixa de ter relação com a ideia de Victor Hugo de abertura de horizontes da arte para os elementos que estão presentes na realidade: não só a beleza, mas também o feio, o disforme e o grotesco devem ser introduzidos na arte para que ela, através do drama, possa representar não só o homem, mas também o todo que o cerca. A harmonia intimamente ligada à beleza na arte clássica demonstra a sua falta de completude, na medida em que não compreende o todo que constitui a vida. O drama é, para
19. HOHOFF, Curt. Heinrich von Kleist. $1777 / 1977,1977$, p. 140. 
20. HUGO, Victor. Do grotesco e do sublime, 2007, p. 49.

21. Ibidem, p. 36.
Victor Hugo, portanto, a forma de poesia que está diretamente associada ao homem moderno, pois ele representa a estética do real, da verdade, que não coloca em cena os homens blindados pela aura da perfeição, mas, sim, simplesmente o homem:

\begin{abstract}
No drama, tal como se pode, se não executá-lo, pelo menos concebê-lo, tudo se encadeia e se deduz assim como na realidade. O corpo representa o seu papel como a alma; e os homens e os acontecimentos, postos em jogo por esse duplo agente, passam alternadamente, cômicos e terríveis, algumas vezes terríveis e cômicos, ao mesmo tempo. [...] Porque os homens de gênio, por grandes que sejam, têm sempre sua fera que parodia sua inteligência. ${ }^{20}$
\end{abstract}

Não há espaço para a idealização que exclui o feio da arte; ao lado do grandioso está o baixo, pois o homem não é só constituído de beleza. A beleza, segundo Victor Hugo ${ }^{21}$, é uma forma que mantém uma simetria e harmonização completas, porém restritas, como se apresentassem apenas uma face, enquanto o feio apresenta mil faces, pois é impuro, passível de mesclas; ele revela a besta humana. Dessa forma, o drama é a poesia completa na medida em que põe lado a lado os contrários da vida real.

Ainda que Victor Hugo tenha pincelado o termo grotesco a partir de metáforas e não o tenha, de fato, sistematizado teoricamente, suas ideias fortaleceram o propósito romântico de desvencilhar a arte nova da antiga, elevando essa categoria ao status de agente diferenciador. Hugo colocou em evidência um processo de construção artística que já figurava na arte romântica com força, fato comprovado pela caracterização que Heinrich von Kleist deu aos personagens de seus dramas.

\section{Penthesilea e Thusnelda: as fúrias kleistianas}

Segundo Victor Hugo, a inserção do grotesco na arte torna esse elemento um ponto de contraste para o sublime, uma forma de elevação do belo que o deixa mais perceptível, pois a contraposição do sublime com o próprio sublime não produz esse contraste: ele dá ao belo "uma coisa de mais puro, de mais sublime"22. Antecipando alguns passos dessas características, Kleist, em Penthesilea (1808) ${ }^{23}$ e em Die Hermannschlacht ( $A$ batalha de Hermann, 1808) ${ }^{24}$, cria duas heroínas, Penthesilea e Thusnelda, que possuem as características do elevado e do baixo: a primeira é uma rainha amazona que é descrita como possuidora de "dignidade e graça", mas que liberta a sua animalidade ao devorar 
o seu amado; a segunda é uma princesa alemã de belos cabelos dourados que, movida por uma vingança, prende o homem que a cortejava em uma jaula para que uma ursa o devore. Assim, percebemos que, nessas duas heroínas, confluem ações moralmente boas e más que provocam o horror diante da mescla de contrários que os dois dramas abordam; é a realidade e todas as suas contradições mais absurdas que são encenadas e que possuem como resultado o elemento grotesco.

A peça Penthesilea conta-nos a história da rainha amazona Penthesilea, que vai à guerra de Tróia com seu exército para capturar bravos guerreiros para a fecundação das guerreiras amazonas. Na guerra, ela se depara com o divino Aquiles, apaixona-se perdidamente por ele e, como somente poderia conquistá-lo por meio da espada, ataca-o vorazmente, até que o herói consegue derrubar a rainha amazona do cavalo. Nesse momento da tragédia, ressoa o mito do encontro de Penthesilea e Aquiles, pois, ao vê-la cair de seu cavalo, o filho de Peleu empalidece e impressiona-se com "seus olhos moribundos"25. Possuído de amor, Aquiles desfaz-se do escudo e da espada e decide dizer a Penthesilea - que não se lembra do ocorrido - que ela o derrotou em combate e que, portanto, ele é seu prisioneiro. Esse embuste será o mote para o desenlace da tragédia. Penthesilea descobre que, na verdade, ela fora abatida por Aquiles. O herói desafia-a para um combate, em que se prostraria aos pés da heroína para cumprir com a sua vontade. Porém, Penthesilea não entende as reais intenções de Aquiles e ataca-o com cães, rasgando-lhe o peito com os próprios dentes. Morto Aquiles, Penthesilea, após um breve momento, recobra a consciência do que acabara de ocorrer e morre aniquilada pela dor de ter matado o seu amor.

Se o tema elegido por Kleist para a composição de sua peça é clássico, a configuração dada ao texto parte de uma visão inteiramente pessoal sobre o mito da rainha amazona, apagando a atitude clássica de comedimento e opacidade para representar um ritual dionisíaco de autodestruição, que nos é mostrado no palco pela exacerbação de sentimentos a que é jogada a heroína da peça. A unidade clássica é tomada de chofre por um turbilhão de sentimentos que são devidamente amparados pela ambientação criada por Kleist para a contextualização das ações dos personagens. Cada ação que se dá no palco tem respaldo nesse mito recriado e ambientado para possibilitar os diversos movimentos que oscilam entre a violência e a brandura, numa tentativa de síntese que procure abarcar, na figura antitética da heroína Penthesilea, a beleza e a sua caracterização grotesca, que realmente a transformam num animal, num monstro em cena.

A heroína é a verdadeira plasmação romântica entre o bem e o mal de que é constituído seu ser, ela é a representante da
25. Esse mito foi narrado no poema épico Etiópica, de Arctino de Mileto, do qual restou apenas um resumo na Crestomatia de Proclo, e também nas Posthoméricas, poema épico de Quinto de Esmirna que narra os eventos que estão entre a morte de Heitor e a queda de Tróia. No mito original, Aquiles mata Penthesilea com uma lança que atravessa seu cavalo e fere-a. O herói, ao olhar em seus "olhos de moribunda", arrepende-se de tê-la matado, pois poderia fazer dela sua esposa. 
26. GUINSBURG, Jaime;

ROSENFELD, Anatol. "Um encerramento”, 2005, p. 292.

27. LUKÁCS, György. "A tragédia de Heinrich von Kleist", 2012, p. 252. busca de uma síntese de elementos contrários que, segundo Rosenfeld e Guinsburg ${ }^{26}$, fez com que Kleist fosse um dos primeiros autores a redescobrir o dionisíaco e com ele celebrar um ritual antropofágico que colocou em evidência o aspecto grotesco que a arte romântica vem agora trazer aos olhos do público. A “desumanização" que Kleist faz da Antiguidade é, segundo Lukács ${ }^{27}$, "uma guinada na história do drama alemão", pois essa modernização e a inserção da barbárie na Antiguidade podem ser entendidas como predecessoras das ideias nietzschianas que fervilharam o século XIX. Assim, essa barbarização da Antiguidade Clássica e a recriação de seus mitos tonalizam uma cultura que estava imersa na pureza e opacidade criadas por clássicos e iluministas, dando a Kleist o mérito de ter sido o pioneiro do dionisíaco no início do século XIX.

Nessa peça, percebemos a construção da heroína por meio de um oxímoro: a sua realidade é baseada nos valores das amazonas e sua insubmissão a qualquer homem, mas também em valores amorosos provenientes de sua condição humana, que lhe despertam o desejo de confessar o seu amor por Aquiles. Essa contradição torna-se evidente quando inconsciência e consciência parecem atuar conjuntamente nas ações de Penthesilea, ou seja, a gradual perda de consciência entra em ação como forma de amenizar o contrato ético estabelecido entre ela e a sociedade de amazonas para possibilitar a realização do desejo, enquanto a consciência deixa ativa a sua índole bélica nos atos de violência e dominação de Aquiles. Dessa forma, ela cria para si e para Aquiles um mundo ideal em que a guerra é a possibilidade de realizar um amor impossível, pois a realidade impede-a de subjugar-se a um guerreiro. É notável em Penthesilea, portanto, uma perda de consciência gradativa, em que o ideal sonhado vai sobrepondo-se à realidade que lhe parece estranha, até o ponto em que, em vista dessa realidade enganosa, o ideal mescla-se ao seu caráter bélico e toma as rédeas na condução da ação, fazendo com que os movimentos de Penthesilea sejam regidos pela fúria incontida de realizar o desejo presente no ideal, mas que, ao mesmo tempo, cumpre com a sua função de guerreira amazona que, literalmente, mata o amor dedicado a qualquer homem.

Assim, os mal-entendidos em que os heróis caem preparam a catástrofe final, em que Aquiles será literalmente consumido pelo amor de Penthesilea. E não há como não pensar que o grande tema dessa tragédia seja o consumo do homem pela realidade, pois o impulso de amor de Penthesilea é movido pelo prazer de alcançar o objetivo inicialmente proposto, porém a dor causada pela consciência da impossibilidade de submissão a esse amor, pela impossibilidade de realização dele, faz a heroína criar um ideal em que possa alcançar a plenitude. A satisfação do prazer infringe a conduta a ser seguida, e nisso reside o em- 
bate entre consciência e inconsciência. Quando a heroína se deixa submeter pela inconsciência, pelo instinto, sua animalidade transparece:

MEROE. [...] Sich über ihn, und reißt - reißt ihn beim Helmbusch,

Gleich einer Hündin, Hunden beigesellt,

Der greift die Brust ihm, dieser greift den Nacken,

Dass von dem Fall der Boden bebt, ihn nieder!

Er, in dem Purpur seines Bluts sich wälzend,

Rührt ihre sanfte Wange na, und ruft:

Penthesilea! meine Braut! was tust du?

Ist dies das Rosenfest, das du versprachst?

Doch sie - die Löwin hätte ihn gehört,

Die hungrige, die wild nach Raub umher,

Auf öden Schneegefilden heulend treibt;

Sie schlägt, die Rüstung ihm vom Leibe reißend,

Den Zahn schlägt sie in seine weiße Brust,

Sie und die Hundem die wetteifernden,

Oxus und Sphinx den Zahn in seine rechte,

In seine linke sie; als ich erschien,

Troff Blut von Mund und Händen ihr herab.28

Ela abocanha justamente o lado esquerdo do peito, o coração, que era o seu alvo. Impossibilitado de ser sentido, seu desejo de possuir o coração de Aquiles é concretizado fisicamente; enquanto ela acreditava cobrir seu amor de beijos, na verdade estava engolindo-o:

\section{PENTHESILEA.}

So war es ein Versehen. Küsse, Bisse,

Das reimt sich, und wer recht von Herzen liebt,

Kann schon das eine für das andre greifen. ${ }^{29}$

O horror e o riso macabro suscitados pela proposição de Penthesilea ao destacar a proximidade sonora dos vocábulos Küsse e Bisse (beijar e morder) ressaltam ainda mais o grotesco da ação. Ela consome literalmente o objeto de seu amor em um ritual antropofágico que a transforma em uma figura grotesca que nada mais nos parece que um dos animais que se servem do corpo de Aquiles. Para Penthesilea, o seu movimento inconsciente condiz às suas intenções: ela queria cobrir o seu amor de beijos, e o seu inconsciente mostrava-lhe isso:

PENTHESILEA.

Wie manche, die am Hals des Freundes hängt,

Sagt wohl das Wort: sie lieb ihn, o so sehr,

Dass sie vor Liebe gleich ihn essen könnte;

Und hinterher, das Wort beprüft, die Närrin!

Gesättigt sein' zum Eke list sie schon.

Nun, du Geliebter, so verfuhr ich nicht.

Sieh her: als ich an deinem Halse hing,
28. KLEIST, Heinrich von.

Penthesilea, 2012, p. 102. Todas

as traduções de citações da peça

Penthesilea são de autoria de

Rafael Gomes Filipe, Edição:

Porto Editora, 2003. "MEROE.

[...] Ela é só mais uma cadela, entre os cães que o abocanham

- este mordendo-lhe o peito, aquele filando-lhe a nuca.

Aquiles, que se revolve nas rubras golfadas do seu próprio sangue, ainda lhe aflora com a mão a mimosa face, e exclama: "Penthesilea, minha noiva, que fazes? É esta a Festa das Rosas que me prometias?". A leoa faminta que, no pertinaz encalço da presa, vagueia uivante por desoladoras campinas geladas, teria ouvido a sua súplica. Mas ela, ela arranca-lhe a couraça do corpo e crava-lhe os dentes no níveo peito; ela e os cães, à compita: Oxus e Sfinx abocanhando o lado direito, ela o lado esquerdo... Quando apareci, escorria-lhe o sangue da boca e das mãos". Idem. Penthesilea, 2003, p. 189.

29. Idem. Penthesilea, 2012, p. 115. "PENTHESILEA. Foi, pois, um erro. Beijar... rasgar... são palavras que rimam. E quem ama de todo o coração, pode pensar uma coisa, e fazer outra". Idem. Penthesilea, 2003, p. 216. 
30. Idem. Penthesilea, 2012, p. 116. "PENTHESILEA.

Muitas são as mulheres que se penduram ao pescoço do amigo e lhe dizem: Amo-te tanto - oh!, tanto!, que seria capaz de te comer! Mas, mal proferiram estas palavras, logo essas tolas ficam saciadas até à repugnância. Eu, porém, meu querido, não procedi assim. Pois, quando te enlacei o pescoço, foi para cumprir a minha promessa - sim - palavra por palavra. Como vês, não estava tão doida como poderia parecer". Idem. Penthesilea, 2003, p. 217.

31. Idem. Penthesilea, 2012, p. 103. "Tão ajuizada, tão cheia de dignidade e de encanto!" Idem. Penthesilea, 2003, p. 190.

32. Idem. Penthesilea, 2012, p. 9. "DIOMEDES. [...] A loba esfomeada não persegue a presa, que o seu olho cruel escolheu, através das florestas cobertas de neve, como ela procura Aquiles por entre as nossas fileiras". Idem. Penthesilea, 2003, p. 17.

33. Idem. Penthesilea, 2012, p. 103. "Ali está ela agora, especada, muda, a atroz criatura, junto do cadáver que a matilha fareja, de olhos fixos no vazio infinito, o arco vitorioso pendente do ombro." Idem. Penthesilea, 2003, p. 190.
Hab ich's wahrhaftig Wort für Wort getan;

Ich war nicht so verrückt, als es wohl schien. ${ }^{30}$

A loucura mescla-se à sensatez que sua condição de guerreira, na realidade, exige, justificando mais uma vez a ação horrenda por um sentimento sublime, o amor. Em estado de inconsciência, concretiza-se aquilo que o amor exige da heroína. Porém, a consciência ordena-lhe a ação bizarra, e a posterior compreensão de sua ação faz com que ela enxergue o horrendo. Sua razão, ao sucumbir ao poderio do instinto, torna-a o espectro da violência; porém, há o indício de uma consciência que a impele ao ato violento. $\mathrm{O}$ contraste instaurado entre um estado e outro é evidente: ao lançar-se ao abismo do inconsciente, a ação de morder Aquiles representa, nesse mundo ideal, o cobri-lo de beijos, ao mesmo tempo em que fica latente em sua consciência a inevitabilidade de tal ação. Morder e cobrir de beijos são, portanto, representantes desse embate entre amor e ódio, esta mescla de contrários de que o grotesco é constituído.

Dessa forma, se inicialmente Kleist caracteriza Penthesilea como uma heroína provida de todos os atributos das heroínas tipicamente clássicas, "So voll Verstand und Wurd und Grazie"31, aos poucos esses atributos são sobrepostos pela sua inclinação à obstinação animal, instintiva, com que busca alcançar seu objetivo de conquistar Aquiles pela espada:

\section{DIOMEDES.}

$[\ldots]$

So folgt, so so hungerheiss, die Wölfin nicht,

Durch Wälder, die der Schnee bedeckt, der Beute,

Die sich ihr Auge grimmig auserkor,

Als sie, durch unsre Schlachtreihn, dem Achill. ${ }^{32}$

A loba Penthesilea caça a sua presa, e essa obstinação alcançará a loucura em seu ápice. A violência que será empregada por Penthesilea já é reflexo das próprias palavras que são proferidas na descrição de suas ações pelos personagens da tragédia. O que antes constituía a dominação de um estado de beleza e elevação é contraposto a uma dominação da natureza instintiva:

\section{MEROE.}

Jetzt steht sie lautlos da, die Grauenvolle, Bei seiner Leich, umschnüffelt von der Meute, Und blicket starr, als wär's ein leeres Blatt, Den Bogen siegreich auf der Schulter tragend, In das Unendliche hinaus, und schweigt. ${ }^{33}$

Se, pensando no ensaio de Kleist, Über das Marionettentheater, por um lado, este estado de inconsciência de Penthesilea equivale à inocência da marionete, que não tem consciência de seus 
movimentos, por outro lado, pode ser entendido como um estado correspondente à consciência total do Deus, uma vez que esta lhe permite enxergar a impossibilidade de realização desse amor, a prevalência do orgulho de que é constituído o seu ser e do seu papel como regente de uma sociedade de mulheres guerreiras. A ação de matar Aquiles é, dessa forma, o único meio de preservar-se e de preservar quem ela deve proteger. Somente a total consciência dessa realidade permite-lhe a ação. A entrega ao estado animal comprova, portanto, a sua entrega real à humanidade que não lhe possibilita vivenciar a experiência amorosa. O homem e a besta unem-se nessa heroína com o propósito de libertação: a volta à ordem necessita dessa ação e da posterior morte de Penthesilea, pois o excesso de orgulho e de amor desequilibrara a ordem natural que constituía a sociedade das Amazonas, e é preciso que Penthesilea e Aquiles sejam abatidos para o retorno ao "paraíso".

Assim, a completude da heroína é comparável à completude da marionete e do urso, seres desprovidos de consciência que conseguem revelar o seu íntimo, a sua vontade suprema através da inconsciência ou da consciência total. A vontade maior de Penthesilea é concretizada através do sonambulismo, que a prepara para a prática da ação que tanto ansiava: chegar à plenitude do amor através da consumação. O ritual antropofágico que ali se processa adquire ares de realização e triunfo sobre a consciência que impedia a consumação do amor. Orgulho e amor somente poderiam ser conciliáveis em Penthesilea por meio desse ritual, em que a heroína consegue subjugar o herói e ao mesmo tempo "cobrir-lhe de beijos", consagrando, assim, a sua vontade. A volta da consciência é também a derrocada da plenitude da amazona, e só a morte poderá conciliá-la novamente consigo mesma.

À vista disso, Penthesilea, que sucumbe à dor após o reconhecimento de seu crime, é metaforizada por Kleist a partir da figura do roble que é arrancado pelo furacão devido à sua frondosa copa:

\footnotetext{
Sie sank, weil sie zu stolz und kräftig blühte!

Die abgestorbne Eiche steht im Sturm,

Doch die gesunde stürzt er schmetternd nieder, Weil er in ihre Krone greifen kann. ${ }^{34}$
}

O orgulho e o amor de Penthesilea ao excesso fizeram com que ela fosse derribada pela impossibilidade de conciliação entre o seu ideal e a realidade que teimava em desfazer seus sonhos. A dor sobrelevada acima dos limites é o mote para a derribada de Penthesilea aos abismos da loucura. A incompatibilidade entre homem e mundo encontra na morte a única possibilidade de unificação do amor que a realidade impede; a morte de
34. Idem. Penthesilea, 2012, p. 118. "Tombou porque florescia soberba, pletórica de seiva! O roble, já sem vida, resiste ao furacão - mas ao que é forte e robusto, a esse derriba-o ele com fragor, pois pode agarrá-lo pela copa!” Idem. Penthesilea, 2003, p. 221. 
35. Idem. Werke in einem Band, 1990, p. 460.

"Schwarz und fett, wie Hexen!" (Todas as traduções de citações da peça Die Hermansschlacht são de minha autoria.)

36. Ibidem, p. 461.

"THUSNELDA: Ah, o quê! Ventidius me disse que isso era um conto de fadas.

HERMANN: Um conto!

Então! Ventidius é muito justo, verdadeiro, para amaciar suas ovelhas para o tempo do tosquio".
Penthesilea é símbolo para essa compreensão de que a realidade nunca lhe será compatível.

$\mathrm{Na}$ peça Die Hermannsschlacht, Kleist recria a batalha em que Armínio, príncipe dos queruscos, derrota o general romano Quintilius Varus na floresta de Teutoburg em 9 d. C. Armínio consegue articular as tribos germânicas e uni-las para derrotar o aparentemente invencível exército romano. Concomitantemente a esse clima bélico, Thusnelda, esposa de Armínio, é impelida por ele a deixar-se cortejar por Ventidius, um legado romano, que se mostra apaixonado por ela: ele a salva de um auroque, com ares de príncipe encantado, e depois corta uma mecha de seus cabelos e pressiona-a apaixonadamente contra os lábios, em sinal de sua devoção à princesa.

Thusnelda, durante toda a peça, é descrita como uma moça ingênua, que, apesar de inicialmente ser forçada pelo marido a agradar Ventidius, deixa-se levar pelas investidas e declarações de amor do legado romano. Armínio alerta-a sobre a possível enganação de Ventidius, que a corteja para poder ter uma aliada germânica na guerra, porém, quando Armínio está para colocar o seu plano de derrotar os romanos em prática, Thusnelda suplica-lhe que poupe a vida de Ventidius. Armínio, então, conta-lhe que encontrou uma carta do legado romano endereçada à princesa Lívia, de Roma, com a mecha de cabelo de Thusnelda, e que o conteúdo da carta revelava que a mecha era uma amostra dos cabelos que Ventidius iria mandar à princesa quando dominasse o povo querusco. Anteriormente, Armínio havia contado a Thusnelda que os romanos, quando conquistam um povo germânico, tosquiam as mulheres de cabelos dourados e arrancam-lhes os dentes de marfim para adornar as princesas romanas, que possuem os cabelos "pretos e gordurosos, como os de bruxas" 35 e os dentes pretos. Ela encara essa mensagem como um conto de fadas, através do riso:

\author{
THUSNELDA \\ Ach, was! Ventidius hat mir gesagt, \\ Das wär ein Märchen. \\ HERMANN \\ Ein Märchen! So! \\ Ventidius hat ganz recht, wahrhaftig, \\ Sein Schäfchen, für die Schurzeit, sich zu kirren. ${ }^{36}$
}

Porém, quando descobre a carta de Ventidius, seu riso transforma-se em horror. Ela fica furiosa e coloca em prática a sua vingança: atrai Ventidius a um parque durante a noite escura - aqui já temos o espaço como atributo sombrio da cena - dizendo que é Gertrud, sua dama, e o tranca em uma jaula com uma ursa faminta. Essa cena leva-nos ao elemento grotesco em Thusnelda, pois ela assiste a tudo impassível, obstinada a 
completar sua vingança. Ventidius suplica a Zeus a misericórdia, porém Thusnelda, longe de impressionar-se com o horror da cena, faz chacota da situação de Ventidius:

\section{VENTIDIUS}

Die zottelschwarze Bärin von Cheruska,

Steht, mit gezückten Tatzen, neben mir! [...]

THUSNELDA

Die Bärin von Cheruska? [...]

THUSNELDA

Thusnelda, bist du klug, die Fürstin ists,

Von deren Haupt der Livia zur Probe,

Du jüngst die seidne Locke abgelöst!

Laß den Moment, dir günstig, nicht entschlüpfen,

Und ganz die Stirn jetzt schmeichelnd scher ihr ab!

VENTIDIUS

Zeus, du, der Götter und der Menschen Vater,

Sie bäumt sich auf, es ist um mich geschehn! [...]

THUSNELDA durch das Gitter

Ach, wie die Borsten, Liebster, schwarz und starr,

Der Livia, deiner Kaiserin, werden stehn,

Wenn sie um ihren Nacken niederfallen!

Statthalter von Cheruska, grüß ich dich!

Das ist der mindste Lohn, du treuer Knecht,

Der dich für die Gefälligkeit erwartet!

VENTIDIUS

Zeus, du, der Götter und der Menschen Vater,

Sie schlägt die Klaun in meine weiche Brust! [...]

VENTIDIUS

Ach! O des Jammers! Weh mir! O Thusnelda!

THUSNELDA

Sag ihr, daß du sie liebst, Ventidius,

So hält sie still und schenkt die Locken $\operatorname{dir} !^{37}$

O riso sombrio de Thusnelda torna ainda mais horrível o ato de crueldade ali encenado. Ela se torna uma figura grotesca que não se animaliza, como Penthesilea, mas que se alia a uma fera para cometer a sua vingança. E não é por acaso que o animal escolhido por Kleist para a composição dessa cena seja uma ursa: por ser uma fêmea, ela se torna o duplo da princesa querusca, o seu lado bestial que é liberto para a vingança. Assim, a própria comparação é estabelecida no diálogo formado entre o trio Thusnelda, Ventidius e a ursa. Ventidius identifica a ursa como "a ursa preta desgrenhada de Querusco", o que segue à pergunta de Thusnelda e a afirmação que se subentende: a ursa é a princesa de Querusco, cujos cachos dourados Ventidius prometeu à princesa Lívia. O contraponto entre os cabelos dourados da princesa e os pelos pretos desgrenhados da ursa estabelecem o duplo, a libertação do grotesco. Além disso, as súplicas de Gertrud durante a ação aproximam muito Thusnelda da ursa:

GERTRUD in die Szene eilend

Du Furie, gräßlicher, als Worte sagen [...]
37. Ibidem, p. 619-620.

VENTIDIUS A ursa preta desgrenhada de Querusco está ao meu lado com as patas contraídas! [...]

THUSNELDA A ursa de

Querusco? [...]

Thusnelda é, você é inteligente, a princesa, de cuja cabeça, para Lívia, como amostra, você recentemente tirou o cacho de seda! Não deixe o momento, favorável a você, escapar, e toda a testa agora lisonjeiramente rape!

VENTIDIUS Zeus, você, pai dos deuses e dos homens, ela se ergue, o que vai acontecer comigo! [...]

THUSNELDA através da grade. Ah, como as cerdas, pretas e rígidas, querido, de Lívia, sua imperatriz, vão ficar se ela cair em torno do seu pescoço! Governante de Querusco, eu lhe cumprimento! Esta é a recompensa mínima, a você, servo fiel, que esperou pelo favor! VENTIDIUS Zeus, você, pai dos deuses e dos homens, ela bate as garras em meu seio macio! [...]

$\mathrm{Ah}$ ! Oh lástima! Ai de mim! Oh Thusnelda!

THUSNELDA Diga a ela que você a ama, Ventidius, assim ela ficará em silêncio e te dará os cachos! 
38. Ibidem, p. 619.

GERTRUD correndo pelo cenário. Você, Fúria, a mais abominável que a palavra diz. [...] - O monstro! Ela a [a chave da jaula] segura em sua mão. Apontando para Thusnelda. [...] A abominável! - Pelos poderes eternos do céu!

39. Ibidem, p. 625.

"Isso já aconteceu. Deixe."

40. LUKÁCS, György. "A tragédia de Heinrich von Kleist", 2012, p. 243.

\section{GERTRUD $[\ldots]$}

- Das Ungeheu'r! Sie hält ihn in der Hand.

Auf Thusnelda deutend.

Gertrud. Die Gräßliche! - Ihr ewgen Himmelsmächte! ${ }^{38}$

Assim como Penthesilea, portanto, a princesa Thusnelda, que possui o título nobre, é bestializada com os atributos de fúria, monstro, abominável, mesclando o baixo e o elevado na composição do drama. Porém, diferentemente de Penthesilea, Thusnelda planeja a sua vingança e é espectadora consciente da morte de Ventidius. Ela somente perde a consciência - desmaia nos braços de Gertrud - quando a ursa já o aniquilou, ela aparecerá novamente na penúltima cena, em que terá apenas uma fala, respondendo ao cumprimento de Armínio por ela ter honrado a sua palavra: "Das ist geschehn. Laß sein"39. Armínio lhe dirá que ela parece pálida, o que nos indica que o ato afetou-a profundamente. Dessa forma, se estabelecermos novamente o intertexto com o Teatro de marionetes, percebemos que essa consciência de Thusnelda assemelha-se muito à consciência total do Deus, do urso que rebate todos os movimentos do esgrimista. Ela passa de um estado de inocência, em que acreditava no amor de Ventidius, e chega a um estado de consciência total, em que entende a verdadeira realidade que a rodeia; na guerra, o amor pode cegar e levar à queda de todo um império.

É impossível dissociar esse drama de Kleist de seu teor nacionalista, uma vez que a peça foi escrita na época em que Napoleão avançava seus domínios sobre o território germânico. $\mathrm{Na}$ condição de militar prussiano, era nítido para Kleist que a corrupção empreendida por Napoleão dos ideais da Revolução Francesa malogrou o pouco que ainda lhe restava de esperança. Essa época fez insurgir no escritor um forte nacionalismo, que foi traduzido em sua obra através de poemas que incitam a violência extrema contra os franceses, e mais especificamente contra Napoleão. É nessa onda reacionária que ele escreve Die Hermannsschlacht, que, segundo Lukács ${ }^{40}$, é "o único drama alemão dessa época no qual o anseio de libertação dos alemães apesar de todos os conteúdos reacionários - é configurado de maneira grandiosa".

Dessa forma, podemos entender a inserção dessa cena emblemática da ursa querusca, portanto germânica, que mata o romano, como uma metáfora da vitória que Armínio empreenderá sobre os romanos e, posteriormente, da possível vitória do germânico ao jugo francês. A alegoria criada por Kleist na peça requer, portanto, essa representação, a partir da figura de Thusnelda, de uma sociedade dominada e que precisa se libertar das amarras que a detém. Thusnelda apenas demonstra que a sociedade deve estar preparada para salvar e libertar a sua nação, mesmo que seja cometendo atos horrendos como o dela. 
A vingança é em Kleist muito presente, a julgar pelos inúmeros personagens que cometem atos vingativos, como Penthesilea, Thusnelda, Michael Kohlhaas, Gustav, etc. Peter-André Alt, em seu artigo "Poetische Logik verwickelter Verhältnisse: Kleist und die Register des Bösen” ("Lógica poética de relações complexas: Kleist e o registro do mal”") ${ }^{41}$, diz-nos que Kleist, em suas obras, faz uma redefinição do mal, tornando-o relativo, diferindo, portanto, da definição do mal contida no escrito kantiano $A$ religião nos limites da simples razãa. Segundo Kant, o mal provém do livre arbítrio do homem e não está ligado a qualquer inclinação física, pois requer o uso da liberdade, que não pode ser ligada aos impulsos sensíveis. A inclinação para o mal no homem está diretamente ligada à faculdade moral do arbítrio, portanto só existe onde há liberdade, o que torna contraditória a ligação da origem do mal à inclinação física, pois só em termos morais é que se pode falar em atos maus. A imputação do bem ou do mal na distinção kantiana às ações humanas tem que estar diretamente ligada ao livre arbítrio, e este, por sua vez, tem de obedecer à lei moral para que esta represente uma máxima do bem, impossibilitando o termo médio no homem entre o bem e o mal. Se a conduta boa ou má tem relação direta com a máxima moral, o que Kant nos irá dizer é que as ações más do homem não implicam em um caráter mau, mas, sim, essas ações devem ser tais que impliquem na inclusão de uma máxima que represente o mal e não o bem. Para que o homem possa ser considerado mau "por natureza", há que estar imbricada nele uma máxima que norteie o seu comportamento e que traduza o seu caráter. Kant deixa explícito que o mal não pode se dar a partir da experiência, mas somente a partir de uma máxima má que foi incluída na moral do homem, daí muitos acharem que o mal é uma característica inata do ser humano.

Para Peter-André Alt, a diferença essencial entre essa concepção e a concepção kleistiana está na definição de Kant de que o mal e o bem não podem coexistir numa mesma pessoa; os textos de Kleist deixam claro que a origem do mal depende do contexto em que se encontra a pessoa que praticou a ação má, podendo coexistir, sim, essas duas instâncias antitéticas. Kleist diz que "Não pode ser um espírito mau o que está no vértice do mundo; é meramente um espírito não compreendido!" ${ }^{42}$, o que abre espaço para uma justificação do mal que parta de uma intenção que serve ao bem:

Zu den dunklen Leidenschaften, die Treibsätze des Bösen bilden, gehören Hass und Ehrgeiz, Gier und Wollust, Argwohn und Wut. Sie lassen sich jedoch nicht nur als Auslöser übler Taten, sondern zugleich als deren konstitutive Elemente betrachten. Durchmischt und versetzt mit zerstörerischen Affekten ist das Böse, das aus der moralischen
41. ALT, Peter-Andre.

"Poetische Logik Verwickelter

Verhältnisse", 2009.
42. Heinrich von Kleist, apud. LUKÁCS, György. "A tragédia de Heinrich von Kleist", 2012, p. 236. 
43. ALT, Peter-Andre.

"Poetische Logik Verwickelter Verhältnisse", 2009, p. 81. Todas as traduções de citações desse texto são de minha autoria. "As paixões obscuras que compõem os encargos propulsores do mal são ódio e ambição, cobiça e luxúria, ira e desconfiança. No entanto, eles podem ser considerados não apenas como a causa de ações más, mas, ao mesmo tempo, os seus elementos constitutivos. Misturando e misturado com as emoções destrutivas é o mal que resulta do auto-esquecimento moral, bem como aquilo que está subjacente à aquisição fraudulenta de motivos morais e da arbitrariedade da violação da norma. Ao contrário de Kant, Kleist não tem em mente a oposição de conceitoschave, mas sim a permanente interdependência de seus contextos explicativos: o mal é produto da confusão ou, com Luhmann, uma situação paradoxal".

44. Jacques Derrida, apud. ALT, Peter-Andre. "Poetische Logik Verwickelter Verhältnisse", 2009, p. 70-71. "O teatro da crueldade não é promovido porque mostra o mal em seu conjunto que lhe afeta, mas pela consistência com a qual revela a improcedência de um mal que tenha perdido a sua estruturação semântica binária”.

45. KLEIST, Heinrich von. Penthesilea, 2012, p. 94. "Meio fúria, meio graça.” Idem. Pentesileia, 2003, p. 175.
Selbstvergessenheit resultiert, ebenso wie jenes, das der Subreption sittlicher Motive und der Willkür des Normverstoßes zugrunde liegt. Anders als Kant hat Kleist dabei nicht die Opposition der Leitbegriffe, sondern die permanente Interdependenz ihrer Begründungszusammenhänge im Auge: das Böse ist das Produkt verwickelter oder, mit Luhmann, paradoxer Verhältnisse. ${ }^{43}$

Não é a destruição do bem pelo mal, mas, sim, a injustiça das ações dos personagens é provocada pelo emaranhado de ambiguidades que os impede de distinguir entre o bem e o mal. Os heróis de Kleist não têm poder de decisão moral, pois, diferentemente de Kant, as ações desses personagens acontecem em um mundo em que é impossível essa diferenciação. O sentido ambivalente que cada ação recebe nesse mundo impossibilita que os personagens consigam discernir se o seu ato pende para o bem ou para o mal. Cegados pela vingança que se torna objetivo mor, os personagens de Kleist estão inseridos em um mundo que ultrapassa as barreiras do bem ou do mal e que causa apenas o engano. Dessa forma, o mal, para Kleist, não está intrincado no homem desde o seu nascimento, mas é uma projeção das ambiguidades criadas por esse mundo de engano. Assim, ele não está enraizado no homem, mas se reflete nele como forma de superar a vivência na realidade; ele é resultado da falta de conhecimento do homem diante do mundo e de si mesmo.

Alt compara esse tipo de composição de Kleist a uma análise que Derrida faz do "teatro da crueldade" de Artaud: este renuncia às concepções de Deus em cena, uma vez que o teatro se torna o espaço onde Deus e suas concepções dão lugar a uma prática cruel que não abarca o teológico. Ele renuncia às diferenças binárias entre o bem e o mal para pôr em cena um mal que não mais faz parte desse sistema binário:

Zum Theater der Grausamkeit avanciert es nicht, weil es das Böse im Ensemble seiner es ermöglichenden Affekte zeigt, sondern durch die Konsequenz, mit der es die Grundlosigkeit eines Übels offenbart, das seine binäre semantische Strukturierung verloren hat. ${ }^{44}$

Nessa eliminação da estrutura binária entre bem e mal, é interessante a inserção de um vocabulário que tenta eliminar essa contradição: quando Aquiles chama Penthesilea de "Halb Furie, halb Grazie" ${ }^{45}$, há uma conversão sintagmática incomum, contraditória em seu cerne, pois une duas instâncias que se opõem; enquanto as Fúrias (ou Erínias) são dotadas de um aspecto horrendo, deusas da vingança encarregadas de punir os crimes cometidos pelos humanos, as Graças (ou Cárites) são as divindades do encanto, que acompanham a deusa Afrodite, a 
deusa da beleza. A aproximação entre dois grupos de divindades tão distantes faz com que a caracterização de Penthesilea penda para a união de opostos que cria uma figura única e grotesca.

Já em Thusnelda, a sua aparência e a da ursa são os pontos que criam a união entre a "bela e a fera", pois Ventidius, na expectativa de seu encontro com a princesa, chama-lhe de “deusa" - "Mir wär die Göttliche so nah?"46 -, o que posteriormente será substituído por "monstro do inferno" - "Was für ein Höllen-Ungetüm erblick ich?”47.

Assim, há uma dificuldade em manter a sublimidade diante do disforme, pois as duas heroínas são completamente descaracterizadas no momento grotesco: adquirem ares de monstro, de fera. Bem e mal, fúrias e graças, belo e feio habitam nessas personagens amalgamando uma forma de teatro que não mais se baseará na grandeza de atos morais presentes nos heróis clássicos. O que choca agora o espectador/leitor é o horror, que provoca medo, espanto, estranhamento.

Kleist dá a Penthesilea e Thusnelda um tom de realidade e crueza que impressiona. Não conseguimos caracterizá-las a partir dos conceitos de bem ou mal pelo crime cometido; elas possuem tamanha profundidade de sentimentos avassaladores que misturam essas duas faces do caráter humano que Kant tanto afastou. A grandiosidade, a imensidão de suas ações está justamente nessa característica, que impossibilita ao espectador o alcance do entendimento diante dessas ações, não sendo possível identificar nenhum extremo, somente um jogo entre esses extremos. Essas figuras kleistianas fazem-nos estremecer de terror diante da crueldade de suas ações, sentimento esse que logo é abrandado por uma compreensão que vai além do ato cometido e busca justificativas para a maldade ali encenada.

\section{Conclusão}

A abertura de visão de que fala Victor Hugo é, em Kleist, uma abertura para entender que a realidade é caótica e que o homem não consegue apreendê-la em essência, e quando vislumbra uma possibilidade de completude, esta é destruída pelo engano, pelo malogro. Mais que a melancolia descrita por Hugo, o que vemos nas obras de Kleist é uma fúria constante. Assim, o inconsciente é um mundo de possibilidades, mas também uma forma de escapar à realidade conturbada, causando a desorientação diante dessa fantasia que é destoante da realidade. O horror é proveniente da própria realidade caótica, e por isso ele reflete a vida em essência, o homem em suas configurações
46. Idem. Die Hermannsschlacht, 1982, p. 618. "A deusa já estaria tão perto de mim?"

47. Ibidem, p. 619. "Que tipo de monstro do inferno eu avisto?" 
grotescas e sublimes. Ao quebrar a estrutura binária entre bem e mal, Kleist atende a mais um quesito dessa nova forma de arte, revelando a mescla de contrários que constitui o homem do mundo moderno. Penthesilea e Thusnelda, dessa forma, são representativas do homem fragmentado na dissonância entre o ser e o parecer, entre o instinto e a razão, entre a beleza e a feiura de homens grotescos.

\section{Referências}

ALT, Peter-Andre. "Poetische Logik Verwickelter Verhältnisse: Kleist und die Register des Bösen”. Kleist-Jabrbuch 2008/2009, Stuttgart, Weimar: J. B. Metzler, 2009, p. 63-81.

ESMIRNA, Quinto de. Posthoméricas. Edición de Francisco A. García Romero. Madrid: Akal, 1997.

GATTI, Icaro Francesconi. A Crestomatia de Proclo: tradução integral, notas e estudo da composição do códice 239 da Biblioteca de Fócio. 2012. Dissertação (Letras Clássicas) - Faculdade de Filosofia, Letras e Ciências Humanas da Universidade de São Paulo. São Paulo, 2012.

GUINSBURG, Jaime; ROSENFELD, Anatol. "Um encerramento”. In: GUINSBURG, Jaime (Ed.). O romantismo. 4. ed. São Paulo: Perspectiva, 2005, p. 275-294. (Stylus, 3)

HOHOFF, Curt. Heinrich von Kleist. 1777/1977. Tradução de Felipe Bosso. Bonn Bad Godesberg: Inter Nationes, 1977.

HUGO, Victor. Do grotesco e do sublime. Tradução e notas de Célia Berrettini. São Paulo: Perspectiva, 2007.

KANT, Immanuel. A religião nos limites da simples razão. Tradução de Artur Morão. Coimbra: Edições 70, 1992.

KAYSER, Wolfgang. O grotesco: configuração na pintura e na literatura. Tradução de Jacob Guinsburg. São Paulo: Perspectiva, 1986.

KLEIST, Heinrich von. Der Zweikampf, Die heilige Cäcilie, Sämtliche Anekdoten, Über das Marionettentheater und andere Prosa. Stuttgart: Reclam, 2012. . Penthesilea. Tradução e Posfácio de Rafael Gomes Filipe. Porto: Porto Editora, 2003. . Penthesilea. Stuttgart: Reclam, 2012. 
. Sämtliche Werke. Herausgegeben von Paul Staf. Berlin;

Darmstadt; Wien: Buch-Gemeinschaft, 1960.

- Sobre o teatro de marionetes. Tradução de José Filipe

Pereira. Estarreja: Acto - Instituto de Arte Dramática, 1998.

Werke in einem Band. Herausgegeben von Helmut

Sembdner. München: Carl Hanser Verlag, 1990.

LUKÁCS, György. "A tragédia de Heinrich von Kleist".

Tradução de Manoela Hoffman Oliveira. Idéias, Campinas, n. 5, p. 234-270, 2012.

SCHILLER, Friedrich. Ausgewählte Werke. Fünfter Band.

Stuttgart: J. G. Cottasche Buchhandlung Nachfolger, 1950.

. Sobre poesia ingénua e sentimental. Tradução, introdução,

comentário e glossário de Teresa Rodrigues Cadete. Lisboa:

Imprensa Nacional-Casa da Moeda, 2003.

SCHLEGEL, Friedrich. Conversa sobre a poesia e fragmentos.

Tradução, prefácio e notas de Victor-Pierre Stirnimann. São

Paulo: Iluminuras, 1994. 
